\title{
Assessing the relationship between student teachers' computer attitudes and learning strategies in a developing country
}

\begin{abstract}
The primary aim of this study is to investigate a possible correlation between the computer attitudes of student teachers and learning strategies in a developing country. The Ohio State University attitudes toward computer technology (OSUACT) scale and learning and study strategies inventory (LASSI) were administered to 124 student teachers. Descriptive results revealed that student teachers possessed positive computer attitudes. Correlational analyses showed that seven learning strategies - attitudes, motivation, time management, concentration, selecting main ideas, study aids and test strategy were associated with computer attitudes. Nevertheless, the results of the multiple regression indicated that the learning strategy that involved the selection of the main ideas was the sole predictor of computer attitudes. The results pointed to the importance of learning strategies in fostering more favourable computer attitudes among student teachers.
\end{abstract}

Keyword: Computer attitudes; Learning strategies; Student teachers; Ohio State University attitudes toward computer technology; OSUACT; Learning and study strategies inventory; LASSI; Developing countries 